\title{
The Study of the Concept of Child-Friendly Schools Programs in the Riverbank Areas of North Banjarmasin
}

\author{
Nina Permata Sari \\ Departement of Guidance and Counseling \\ Lambung Mangkurat of University \\ Banjarmasin, Indonesia \\ nina.bk@ulm.ac.id
}

\begin{abstract}
This study aims to design the concept of ChildFriendly Schools programs for elementary schools in the riverbank areas of North Banjarmasin. The concept used is based on the Guidelines for Child-Friendly School Development Stages compiled by the Ministry of Education and Culture (2016) in The Guide ofChild-Friendly Schools in Primary Schools. The population of this study is ten elementary schools of North Banjarmasin which is near to the riverbank area. The sample in this study was taken using a purposive sampling technique; they are five schools namely SDN Kuin Utara 5, SDN Alalak Utara 1, SDN Sungai Andai 3, SDN Sungai Jingah 1, dan SDN Sungai Miai 1. The variable examined in this study is a single variable namely "Child-Friendly Schools in the riverbank area." The data is collected through a questionnaire, observation, and unstructured interview. The data is analyzed using qualitative descriptive analysis.
\end{abstract}

Keywords-Child-Friendly School; Elementary School; Riverbank Area.

\section{INTRODUCTION}

School is an educational institution that helps students to develop their potential optimally, not only in the cognitive aspects but also in the psychomotor and affective aspects, namely teaching, guiding, and directing student to the aspects of personality, attitudes, values, and character in behaving. Reference[1] that the functions of school are to provide students to obtain the knowledge that they need in their lives, to develop the skills needed, to teach students to be able to live together and work together with others, and to help students bring their dreams into reality and to be able to place themselves according to their potential

To actualize all the functions of the school above, consequently, it is essential for schools as educational institutions to be a pleasant, comfortable environment and make students feel comfortable at school. Almost all of the time students have is spent in school. Additionally, since the most critical times in human life are childhood, especially at elementary school, to support optimal growth and life development of children, a good environment is needed. The environments referred here are a home and school environment that can fulfill the rights of life needs of children. Thus they can grow, learn and develop according to their potential optimally.
The ideal school environment refer to The Guide of Child Friendly Schools in Primary Schools [2]. The Guide states that every student has the opportunity to have children's rights for education without discrimination based on disability, gender, ethnicity, religion, and parents' background. Consider the importance of students' best interests as the main consideration in the management and administration of education. Creating an environment that respects the dignity of students and guarantees a student's holistic and integrative growth and development. Appreciate and respect students' perspectives to express their views and be taken seriously by educators; and good governance, which guarantees transparency, accountability, participation, openness of information, and the rule of law in schools.

However, the ideal conditions regarding child-friendly schools proclaimed by the Indonesian Ministry of Education and Culture above do not appear to have been done by educators in some schools. Especially at the elementary school level (SD), it is found that there is still violence that occurs in schools, based on reports from The Banjarmasin Integrated Service Center for Women and Children Empowerment (P2TP2A), the cases of violence against women and children are continually increasing, recorded in 2017 there was 37 cases of sexual, psychological, and physical abuse [3]. The data from South Kalimantan Department of Women's Empowerment and Child Protection (DPPPA)shows that by 2018 the case has been continued to increase with 78 cases of sexual harassment and 21 cases of physical violence.

This is certainly not synergized with the establishment of Banjarmasin as the Child Worthy city in the primary category since 2017, which relates to the need to fulfill children's rights, one of which is through the existence of Child-Friendly Schools. Therefore, the acceleration of the development of Child-Friendly Schools according to the standards set by the government is an important issue that must be followed up by the Banjarmasin city government by discerning the data that occurs regarding the insolence received by students, especially in schools as the educational institutions.

Regarding the focus of the concept study of child-friendly school programs in the river banks of North Banjarmasin, the reason is that Banjarmasin has unique characteristics that are different from other cities in Indonesia. The city is also an area 
that has a very complicated life system, contributing to the formation of a very dynamic and competitive life system, fast information system, and various other life opportunities and challenges. Under the circumstances, this affects the characteristics of the community [4]. The city of Banjarmasin is often referred to as the city of a thousand rivers, the word Banjar means villages or rows of houses built in rows or lined along the banks of the river. This city is formed by five small streams, which are Sipandai river, Sigaling river, Keramat river, Jagabaya river, and Pangeran river, that all of them linked and then formed as a lake.

The riverbank community is the people who tend to settle around the riverbanks. In swamp and riverbanks, houses are built in rows facing the river or facing each other with a highway and a river behind by one of the rows of houses [5]. Generally, the house is located on the edge of the river or sometimes consumes a river body that can be rationally understood to make it easier for homeowners to access the river for various purposes. It can be concluded that the riverbanks community is the people who live in the riverbank areas that carry out almost all of their life activities using the river as the media, there is a multifunctional building that floats on the edge of the river called Batang. Batang serves as a bathing place, washing, and restrooms and becomes a small port as a stopover for various types of boats, from kelotok to jukung [6]. Children usually use Batang for multiple types of river games such as swimming, racing on the water, or pushing each other on Batang fall into the river. People who lives in riverbanks tend to utilize what is in their environment as a support for their lives.

Besides that, the people of Banjarmasin who live in the riverbanks are socio-economically in the middle to lower category so that this affects family's upbringing in educating their children, inconsequently this indirectly influences the interaction of children in school. Also, the condition of the area close to the river makes the activities of children play and interact with their friends more in the river which gives rise to distinctive characteristics that exist in children of the riverbanks [5].

Based on the statements above, a child-friendly school program is essential to be applied ideally in schools, especially elementary schools in the city of Banjarmasin along the river so that the goals and functions of education can be accomplished optimally. Through this study, a draft concept of a child-friendly school program in the city of Banjarmasin can be made in a riverbank area based on The Guide to Child Friendly Schools in Primary Schools [2]. Hence the researcher is interested in conducting qualitative research study with title "The Study of the Concept of Child-Friendly Schools Programs in Riverbank Areas of North Banjarmasin."

The purpose of this study is to find out the concept of a child-friendly school program in the riverbanks of North Banjarmasin.

\section{LITERATURE REVIEW}

\section{A. Child-Friendly School}

\section{1) The definition of Child-Friendly School}

The definition of child-friendly school according to reference [7], is the elementary schools which have security, clean, healthy, caring and cultured environment that can guarantee, fulfill, respect children's rights and protect children from violence, discrimination, and other mistreatment and support children's participation especially in planning, policy, learning, supervision, and complaints mechanism related to the fulfillment of children's rights and protection in education.

The concept of a child-friendly riverbanks school program in this study refers to the Guidance for the Child-Friendly School of Elementary Students [2] based on the following principles:

- Non-discrimination is guaranteeing the opportunity of every child to have the right of having education without discrimination based on disability, gender, ethnicity, religion, and parents' background;

- The best interests for children are always being the main consideration in all decisions and actions taken by education managers and organizers relating to students;

- The right to life, survival, and growth is to create an environment that respects the dignity of children and guarantees children's growth holistically and integratively;

- Respect for children's perspectives, which includes respect for children's rights to express perceptions, which is taken seriously; and

- Good governance, which guarantees transparency, accountability, participation, the openness of information, and the rule of law in elementary schools.

\section{2) The Riverbank Area}

The river is a water irrigation system from the springs to the inlet with its right and left bounded along the drainage by the borderline, as one of the water resources that are useful for the life and the livelihood of the community [8]. Besides that, the river is a part of the earth's surface which is located lower than the surrounding land and the place where freshwater flows to the sea, lake, swamp, or another river [9].

While the riverbank is different from the river border, the riverbank is a border area that the left and right of the river are affected by river over following. Riverbank is a land on both sides along the river through that is calculated from the edge to the foot of the inner dam. Ecologically, the river borders are the habitats where the biological components of the river develop [5].

The province of South Kalimantan is the region with geographical and demographic conditions dominated by riverbanks, especially in Banjarmasin. More than 60 rivers are flowing. The area that is the focus of this study is the schools where placed on the edge of a riverbank in North Banjarmasin, namely Jingah river, Miai river, Kuin river, Alalak river, and Andai river. Discussing riverbanks is not only about managing 
the physical material management of riverbanks but also examines the characteristics that socio-culturally occur from people who live in the riverbanks.

Rivers in the Banjar neighborhood, especially in the city of Banjarmasin have a significant influence on people's activities in daily life. Therefore, rivers become water transportation infrastructure, residence area, and the place where the transaction or traditional market takes place, which is wellknown as the floating market [5]. Furthermore, elementary school children's activities for the game arena and their playing time, they tend to be spent more around the river banks in their settlements, they can bathe in the river for hours, fish, paddle boats, etc. Thus, the characteristics that arise in children who live in the riverbank area are very active, enjoying outdoor activities, using rough motor activities, tough, not sappy, outgoing, and stubborn because of the results of the forging from the hard life of the riverbanks.

\section{3) Characteristics of Elementary School Age Children}

Primary school age is a late childhood that lasts from the age of six to approximately eleven or twelve years. In this age, children firstly experience formal education and can be said that this age is a mature age to receive lessons that are the first level in education as the provisions in the future to pursue higher levels of education. The elementary school age is wellknown as the initial basis in determining children's development in the future. Therefore, a teacher is expected to provide an excellent environment to be able to help students to develop optimally in the learning process [10].

The primary school period is divided into two phases, as follow:

The period of low-grade elementary school (6 years old to 10 years old) Some characteristics of children during this period are below:

- There is a high positive correlation between physical conditions and school performance;

- Subservience toward the traditional rules of the game;

- The tendency to praise themselves, like to compare themselves with other children, if this feels favorable, in this case, there is a tendency to belittle other children: If they cannot solve a problem, then the matter is considered not important;

- At this age (especially at the age of 6-8 years), children want the highest scores or a good report book, without considering whether their achievements deserve good scores or not.

- The period of high-grade elementary school (about the age of 9 years to approximately the age of 13 years) below:

Some characteristics of children during this period are

- Having an interest in concrete daily practical life, this leads to a tendency to compare practical works;

- Very realistic, curious, want to learn;
- Towards the end of this period, there have appeared interests in specific things and subjects.

- Before the age of 11 , children need a teacher or other adults to help them complete the task, after the age of 11 , children generally face their task freely and try to solve it by themselves;

- At this period children view grades (report card grading scale) as the right measure (as well as possible) regarding school achievement;

- Children at this period like to form groups as a means to play together [11].

\section{METHOD}

The method of the study employed qualitative research with the descriptive design, which aims to describe the concept of Child-Friendly school programs in the riverbanks of the city of North Banjarmasin factually and accurately regarding the facts, the nature and the relationship between the phenomena investigated [11].

TABLE I. DISTRIBUTION OF SAMPLES OF THE STUDY

\begin{tabular}{|l|l|l|l|}
\hline \multicolumn{1}{|c|}{ Sub-District } & \multicolumn{1}{|c|}{$\begin{array}{c}\text { Total of } \\
\text { Schools }\end{array}$} & $\begin{array}{c}\text { School located in } \\
\text { the riverbank } \\
\text { area }\end{array}$ & $\begin{array}{c}\text { A Sample of } \\
\text { The Study }\end{array}$ \\
\hline $\begin{array}{l}\text { North } \\
\text { Banjarmasin }\end{array}$ & 41 & 10 & 5 \\
\hline
\end{tabular}

The population of this study is ten elementary schools in the city of North Banjarmasin that located in the riverbank area. The sample of this study has been taken using purposive sampling technique; those are five elementary schools, namely SDN Kuin Utara 5, SDN Alalak Utara 1, SDN Sungai Andai 3, SDN Sungai Jingah 1, and SDN Sungai Miai 1. The reason the researcher chose the location because the location of the schools is close to the settlement of people living in the riverbank area. The data were collected using observation and unstructured interview — data analysis used qualitative descriptive analysis. The variable examined in this study is single variable namely "Child-Friendly school in the riverbank area."

\section{Result And Discussion}

The result is made based on interview and observation from some correspondents, namely principals, teachers, students, parents/guardian committee, and community leaders. The schools have been the setting of the research the schools in the riverbank area namely SDN Kuin Utara 5, SDN Alalak Utara 1, SDN Sungai Andai 3, SDN Sungai Jingah 1, dan SDN Sungai Miai 1. The design of the concept of child-friendly schools with the implementation system adjusts to the characteristics and conditions of public elementary schools located in the riverbank area of North Banjarmasin. 
TABLE II. THE CONCEPT OF CHILD-FRIENDLY SCHOOLS BASED ON CHILD-FRIENDLY SCHOOL GUIDANCE IN ELEMENTARY SCHOOLS [2]

\begin{tabular}{|c|c|}
\hline Component & Indicators of Implementation \\
\hline \multirow[t]{4}{*}{ Non-discrimination } & $\begin{array}{l}\text { Every child has the right to get the } \\
\text { opportunity to go to school near their } \\
\text { place of residence. }\end{array}$ \\
\hline & $\begin{array}{l}\text { In the teaching and learning } \\
\text { processes, teachers do not } \\
\text { discriminate students based on } \\
\text { religion, ethnicity, social status, } \\
\text { economic level, and family } \\
\text { background and students' ability. }\end{array}$ \\
\hline & Free tuition fees \\
\hline & $\begin{array}{l}\text { School supplies are given free (school } \\
\text { uniforms, sportswear, textbooks, and } \\
\text { stationery). }\end{array}$ \\
\hline \multirow[t]{4}{*}{$\begin{array}{l}\text { Prioritizing behalf of students in } \\
\text { making decisions and actions of } \\
\text { educator }\end{array}$} & $\begin{array}{l}\text { Involving all the stakeholders in the } \\
\text { management and the implementation } \\
\text { of education, such as the education } \\
\text { office, principals, councils, teachers, } \\
\text { students, education staff, } \\
\text { parents/guardian committee of } \\
\text { students and community leaders for } \\
\text { the implementation of activities and } \\
\text { policies that support positive } \\
\text { development for students in riverbank } \\
\text { schools. }\end{array}$ \\
\hline & $\begin{array}{l}\text { The policy adapts to the unique } \\
\text { characteristics of the economic, } \\
\text { social, cultural, religious and } \\
\text { character conditions of students in the } \\
\text { riverbank area. }\end{array}$ \\
\hline & $\begin{array}{l}\text { The policy adapts to the facilities and } \\
\text { supporting facilities owned by the } \\
\text { school. }\end{array}$ \\
\hline & $\begin{array}{l}\text { Paying attention and striving to } \\
\text { improve the quality and quantity of } \\
\text { infrastructures. }\end{array}$ \\
\hline \multirow[t]{5}{*}{$\begin{array}{l}\text { The right to life, viability, students' } \\
\text { development. }\end{array}$} & $\begin{array}{l}\text { Creating an environment that supports } \\
\text { students' growth and development in } \\
\text { a holistic and integrative manner. }\end{array}$ \\
\hline & $\begin{array}{l}\text { Creating teaching and learning } \\
\text { processes that support students' } \\
\text { growth and development in a holistic } \\
\text { and integrative manner. }\end{array}$ \\
\hline & $\begin{array}{l}\text { Providing facilities that can develop } \\
\text { students' development in the aspects } \\
\text { of cognitive, affective and } \\
\text { psychomotor. }\end{array}$ \\
\hline & $\begin{array}{l}\text { Identifying the strengths and } \\
\text { weaknesses of characteristics that } \\
\text { children have on the riverbank as a } \\
\text { basis for developing the school's } \\
\text { vision and mission. }\end{array}$ \\
\hline & $\begin{array}{l}\text { Respecting the dignity of students as } \\
\text { individuals who have individual } \\
\text { differences. }\end{array}$ \\
\hline \multirow[t]{3}{*}{$\begin{array}{llll}\text { Respect } & \text { students' } & \text { views } & \text { and } \\
\text { opinions. } & & & \\
\end{array}$} & $\begin{array}{l}\text { Respecting and appreciating students' } \\
\text { thoughts and views both in teaching } \\
\text { and learning processes. }\end{array}$ \\
\hline & $\begin{array}{l}\text { Asking for an opinion from students' } \\
\text { point of view on policies that have } \\
\text { been, are being and will be held by } \\
\text { the school. }\end{array}$ \\
\hline & $\begin{array}{l}\text { Giving the opportunities and place to } \\
\text { students for expressing and pouring }\end{array}$ \\
\hline
\end{tabular}

\begin{tabular}{|l|l|}
\hline Component & \multicolumn{1}{|c|}{ Indicators of Implementation } \\
\hline & $\begin{array}{l}\text { out all the positive ideas they have } \\
\text { freely and responsibly. }\end{array}$ \\
\hline $\begin{array}{l}\text { Giving the lesson about sex education } \\
\text { and protecting students from sexual, } \\
\text { physical and psychological violence. }\end{array}$ \\
\hline $\begin{array}{l}\text { Teaching and guiding students to be } \\
\text { responsible to respect others' opinions }\end{array}$ \\
\hline $\begin{array}{l}\text { Guiding students to tolerate toward } \\
\text { pluralism in their environment. }\end{array}$ \\
\hline $\begin{array}{l}\text { Helping children to be able and } \\
\text { skilled in solving their problems that } \\
\text { arise in themselves from personal } \\
\text { aspects, academic aspects, and social } \\
\text { and career aspects. }\end{array}$ \\
\hline Good governance & $\begin{array}{l}\text { Managing the school's management } \\
\text { based on legal laws. }\end{array}$ \\
\hline $\begin{array}{l}\text { Guarantee transparency, } \\
\text { accountability, participation and } \\
\text { openness of information on aspects of } \\
\text { financing, education, information } \\
\text { related to programs and improving the } \\
\text { quality of learning. }\end{array}$ \\
\hline $\begin{array}{l}\text { The principal has an active role in } \\
\text { supervising and mentoring teachers, } \\
\text { involving teachers and school } \\
\text { committees in school governance }\end{array}$ \\
\hline $\begin{array}{l}\text { According to UU No.20/2003 act 49 } \\
\text { about National Education System that } \\
\text { school governance in the management } \\
\text { of education should implement a } \\
\text { school-based management system } \\
\text { based on independence, transparency, } \\
\text { participation, and accountability. }\end{array}$ \\
\hline
\end{tabular}

Non-discrimination is guaranteed the opportunity for every student to get the right to have an education without being discriminated based on disability, gender, ethnicity, religions, and family's background. The tendency of socio-economic status of the people in the riverbank area, especially in North Banjarmasin, is in the middle to lower classification with average income from \pm 1.000 .000 to 2.000 .000 . The majority of the people is more than $90 \%$ adherents of Islam and is very strong with religious values in their communities, the Banjar tribe, but some of them are Javanese, Madurese and Dayak tribes. In addition to the educational background of parents, only elementary and junior high school graduate.

The concept of designing child-friendly schools in riverbanks area is not to discriminate students, and they have the right to get the opportunity to get an education. In teaching and learning processes, teachers do not discriminate students based on religion, ethnicity, social status, economic status, family's background, and students' ability since students are intelligent but in different fields of abilities. Some students are best at drawing, math, music, writing stories, sports, reciting Qur'an, etc. They will able to develop their abilities optimally if they are stimulated in the right way according to the type of abilities of each [11].

The greatest behalf of students is always to be a primary consideration in all decisions and actions that are related to students taken by the educators. The policies, the decisions, and the actions taken by the school are always based on the best behalf of the students. To be more effective, the implementation of education should require clear, complete 
and integrated planning by involving all stakeholders to jointly discuss in determining education policies in the school [12] so that activities and policies that support the positive development are carried out for students in river banks.

The right to life, viability, and students' development mean creating an environment that respects student dignity and guarantees students' development in a holistic and integrative manner - the characteristics that occur in children in the riverbanks who tend to be very active, enjoying outdoor activities, using rough motor activities, tough, not sappy, outgoing, and stubborn. It's because of the results of the forging from the hard life of the riverbanks [5]. Therefore, the implementation of child-friendly schools can create and support children's growth and development in a holistic and integrative manner. Every student is intelligent and equipped with various abilities that they have. So that, there is a freedom for students to be creative based on their interests and talents without being pressured by adults, educators, and parents, and should be supported by a friendly educational environment [4].

Respecting students' views means the educators respect the rights of children to express their views and be taken seriously. The educators respect and appreciate students' views and opinion, and they also give students the opportunity and place to express their definite ideas freely and responsibly. The educators guide students to tolerate toward the pluralism in their environments and help them to be able to solve their problems that occur in themselves in the aspects of individuals, academic, social and career. Consequently, the positive supports make the students feel more valuable [13].

Good school governance means that guarantying transparency, accountability, participation, and openness of information, also legal supremacy in elementary school. According to reference [14], that school governance in the management of education should implement a school-based management system based on independence, transparency, participation, and accountability. In this case, the Principal has the primary authority to be responsible for preparing adequate infrastructure, competent teachers, proper management, and open, creative and has a high morale [15].

\section{CONCLUSION}

The concept of a child-friendly school program in the riverbank area of North Banjarmasin is concerned with the following aspects:
- Non-discriminative

- Prioritizing behalf of students in making decisions and actions of educator

- Guarantying the right to life, viability, and students' development.

- Respecting and appreciating students' views and opinions.

- Good school governance.

\section{REFERENCES}

[1] M. Ali, Pendidikan Untuk Pembangunan Nasional. Grasindo. Jakarta, 2009.

[2] D. Atmono, Tata KelolaSekolah Dasar Negeri di Kota Banjarmasin. Bappeda Kota Banjarmasin, 2014.

[3] Kemendikbud, Panduan Sekolah Ramah Anak di Sekolah Dasar. Kementerian Pendidikan dan Kebudayaan, Direktorat Jenderal Pendidikan Dasar dan Menengah, Direktorat Pembinaan Sekolah Dasar, 2016.

[4] M. Paramita, Dari Surakarta Mendesain Kota LayakAnak Indonesia. Hunian Rakyat CaritraYogya. Yogyakarta: 2014.

[5] Nasrullah, "Masyarakat dan Kebudayaan Sungai". Bahan Ajar. Program Studi Pendidikan Sosiologi dan Antropologi, FKIP ULM., Banjarmasin, 2017.

[6] Indonesian Ministry of Education and Culture, 2016.

[7] Nasrullah, "Sungai dan Angan-angan sepotong Surga. Makalah di sampaikan dalam Konsultasi Nasional mahasiswa Teologi Indonesia". Banjarmasin, 2016.

[8] G. J. Brierly and K. A. Fryirs, Geomorphology and River Management: Applications of the River Styles framework. Blackwell Science, Oxford, UK, 2005.

[9] A. Maryono, "Kajian Lebar Sempadan Sungai (Studi Kasus Sungaisungai di Provinsi Daerah Istimewa Yogyakarta)", Jurnal Dinamika Teknik Sipil. Vol. 9, No.1, pp. 56-66, 2009.

[10] H. B. Elizabeth, Child Growth and Development.. Literary Licensing: USA, 2013.

[11] Sugiyono, Cara Mudah Menyusun Skripsi, Tesis dan Disertasi. Alfabeta. Bandung, 2014.

[12] A. Tholib, Strategi Implementasi Kebijakan Manajemen Peningkatan Mutu Berbasis Sekolah dengan Pendekatan MMT. Bandung: Dewi Ruci. 2009.

[13] J. Ghicara, Mendidik Anak Sepenuh Jiwa. Jakarta: Gramedia, 2013.

[14] UU No.20/2003 pasal 49 ayat 1 about National Education System.

[15] Kompri, Standarisasi Kompetensi Kepala Sekolah (Pendekatan Teori Untuk Praktik Profesional). Jakarta: Kencana, 2017 